\title{
The Psychological Security Level of the Disabled Children in Qatar
}

\author{
Abdulnaser A. Fakhrou ${ }^{1}$, Zahrah Mousa Jaafar $^{2}$ \& Sara A. Ghareeb ${ }^{3}$ \\ ${ }^{1}$ College of Education, Qatar University, Qatar \\ ${ }^{2}$ College of Education for Humanities, University of Diyala, Baquba, Iraq \\ ${ }^{3}$ Ministry of Education, Kuwait \\ Correspondence: Dr. Abdulnaser A. Fakhrou, College of Education, Qatar University, Qatar. E-mail: \\ afakhrou@qu.edu.qa
}

Received: June 9, 2020

Accepted: June 29, 2020

Online Published: July 24, 2020

doi:10.5430/irhe.v5n2p67

URL: https://doi.org/10.5430/irhe.v5n2p67

\begin{abstract}
The present study aimed to explore the psychological security level of the disabled children in Qatar. The sample consists from 2735 female and male children. The psychological security scale was used. This scale was developed by Habeeb (2013). It consists from 20 items. It sheds a light on four dimensions of psychological security; (personal security, social acceptance, emotional security, and self-esteem). The validity and reliability of the scale were measured and considered satisfactory. It was found that the mean of the emotional security is ranked first, followed by the means of social acceptance, personal security and self-esteem respectively. It was found that the psychological security level of the respondents is moderate. It was found that the psychological security level is not affected by the type of the family that one lives in. The types of families include: stable families, families in which the parents are divorced and families in which one of the parents passed away.It was found that the psychological security level isaffected by the disability type. It was found that the psychological security level is affected by the type ofthe school that one is enrolled at. For instance, the students enrolled in public schools show a higher psychological security level than the students enrolled in private schools. The researchers suggest several recommendations and suggestions for researchers.
\end{abstract}

Keywords: psychological security, disability, Qatar

\section{Introduction}

Much attention has been always provided for physiological and psychological needs by psychologists, especially by the researchers specialized in developmental psychology.Meeting one's psychological needs plays a significant role in meetinghis/her social and security related needs. It makes one feels safe. It enables one to meet his/her needs in accordance with the society's demands and interests.

During the childhood stage, there are important physical, psychological and security-related needs that must be met. However, children are incapable of meeting such needs. That is because children are not fully developed yet. One's psychological security is affected by the way he/she interacts with people in his/her surrounding environment. It is affected by the expertise he/she gains throughout his/her life. It is affected by several environmental, social, political, and economic factors. Ensuring thatthe child enjoys a high psychological security level is considered essential. That is because psychological securitysignificantly affects the development of one's personality. However, one can't enjoy a high psychological security levelwithout having his/her needs met (Jaber, 1996, 80, Mursi, 1996, 81).

For sure, one's capability to adjust socially is affected by the degree to which he/she feels secure during childhood. To illustrate more, if the child was raised up in a secure environment that's full of love, he/she shall develop in a healthy manner. In such a case, he/she shall become capable of meeting his/her goals in the future. If the child wasn't raised up in a secure environment that's full of love, he/she shallnot develop in a healthy manner. He/she shall not be capable of meeting his/her goals in the future.He/she shall experience behavioral problems.Psychological security has been receiving much attention by officials, and activists in society. That is because psychological security affects one's behavior and way of dealing with others.Enjoying a high psychological security level is a blessing. 
The psychological security of disabled people has been receiving more attention than the psychological security of normal people.That is because disabled people face many difficulties, especially in education, psychological and social areas (Al-Qaryooti et al., 1995: 42-46, Aqra', 2005, 6-4).

The extent of attention that is given for disabled people reflects how developed the state is. It reflects the solidarity level in the society. Hence, governments have been providing much attention to the establishment of schools and centers for disabled people. These schools and centers are established to integrate disabled people into society. They are established to reduce the severity of the negative impacts of disability on disabled people. They aim at enabling disabled people to achieve self-realization, despite their limited potentials

Providing disabled people with a secure environment shall make them enjoy a high psychological security level. In addition, it enables disabled people to contribute to the development of society. Therefore, the Qatari governmentprovides seek providing special care for disabled people. For instance, it signed the Convention of the Rights of Persons with Disabilities of 2006. The United Nation signed the latter convention on 13/12/2006. This convention is an international human right treaty. It aims at protecting disabled people and their rights. It aims at providing disabled people withopportunities. There are about 650 million disabled individuals worldwide. Today, governmentsshould sign conventions and enact laws that protect disabled people and their rights. Doing that shall ensure that disabled people enjoy the rights that normal people enjoy in terms of education, recruitment and social life.

The Qatari government and Qatari private institution have been exerting much effort for providing disabled people with care. Therefore, it is necessary to identify whether disabled children in Qatar enjoy a high psychological security level or not. Enjoying a high psychological security level by disabled children shall enable those children to unleash their potentials. It shall enable them to utilize their capabilities and adjust socially with others.

The present study aimed to explore the psychological security level of the disabled children in private and public schools in Qatar. The dimensions of psychological security are: (personal security, social acceptance, emotional security, and self-esteem). The results of the present study can be used for developing effective programs for raising the psychological security level of the disabled children in Qatar. To be more specific, the present study aimed to answer the following questions:

Q.1. What is the psychological security level of the disabled children in Qatar?

Q.2. Is there any statistically significant difference between the respondents' psychological security levels which can be attributed to their (gender, family type, disability type, and the type of institution)?

\subsection{The Study's Significance}

The present study is significant because it aimed to explore the psychological security level of the disabled children in Qatar. It is significant because it aimed to explore the relationship between the latter level from one hand and (gender, family type, disability type, and the type of institution) from another hand. The results of the present study can be used for developing strategic plans for providing special care for disabled individuals in educational institutions.

\subsection{The Study's Objective}

The present study aimed to explore the psychological security level of the disabled children in Qatar. It aimed to explore the relationship between the latter level and other variables (i.e. gender, family type, disability type, and the type of institution).

\subsection{The Study's Limits}

The present study targets disabled children in Qatar. It was conducted during the academic year (2019/2020).

\subsection{Definition of Terms}

- Psychological security (operational definition): It refers to the overall score of the respondents on the psychological security scale.

- Disabled children (operational definition): This term refers to the children who suffer from a disability regardless of its type. Those children are considered disabled based on the standards of the Ministry of Education and Higher Education in Qatar. They are either enrolled in private or public schools. 


\section{Theoretical Framework}

\subsection{Psychological Security}

Psychological security refers to the state in which one is free from any fear and isn't worried about his/her health, job, future, children and rights. In case one anticipated harm on any of these things or faced a threat in this regard, he/she shall lose his/her sense of security. To enjoy psychological security, one must:

1)-exert effort to be loved and supported by people. He/she make people satisfied with his/her behavior. He/she must exert effort in order for people to care about him/her.Exerting such efforts shall make one feel that he/she has people who shall support him/her when needed. In addition, the government must take various measures for ensuring that people enjoy a high social security level.

2)-have much adequate knowledge and skills that enable him/her to strive for enjoying good living conditions.

3)-enjoy a high self-confidence level. Enjoying a high self-confidence level shall significantly affect one's psychological security. Feeling inferior and being incapable of addressing daily life problems shall negatively affect one's psychological security.

Similar to adults, children are in need for enjoyingpsychological security. However, the extent of children's need for enjoying psychological security is higher than the extent of adults need for that. That is because children are weaker than adults and possess less knowledge than adults. Meeting the physiological needs of children shall increase their psychological security level. Making the children feel loved by their parents and interacting with them emotionally shall increase their psychological security level. In other words, parents must provide their children with care, play games with them, answer their questions, and inform them about the behaviors that are unaccepted. Doing these things shall increase children's psychological securitylevel (Rajeh, 2011: 113).

Rezq (1979) defines psychological security as the degree to which one enjoys self-esteem, security and self-confidence. It also refers the state to which one doesn't have any fear nor worries about his/her health, future and social status. It involves the degree to which one trusts others (Rezeq, 1979). Zahran (1989) suggests thatpsychological security refers to having healthy relationships between one from one hand and himself/herself and others from another hand. If one has such healthy relationships, he/she shall enjoy much stability. Having such healthy relationships shall positively affect one's productivity. It shall reduce the probabilities of experiencing anxietyand disorders (Zahran, 1989). The psychological security level represents the extent of protection that one needs to protect his/her academic life, job, food and clothes (Rezeq, 1979: 62, Al-Kenani, 1985: 93, Zahran, 1989: 296).

Psychological security doesn't involve one aspect only. In fact, it involves physical, social, affective, and cognitive aspects. There is a significant positive relationship between psychological security from one hand and social security and psychological welfare from another hand. Psychological security has several dimensions. Such dimensions may include: self-acceptance, having positive relationships with others, autonomy, and personal development. They may include: having control over the surrounding environment. There are several factors that affect the degree to which one enjoys psychological security. Such factors include the following ones:

1)- Socialization: The way of raising one shall significantly affect the degree to which he/sheenjoys psychological security. The nature of one's social relationships affects his/her psychological security. The extent of providing one with love affects his/her psychological security. The extent of enjoying social acceptance and stability affects one's psychological security.

2)- Environmental factors: The surrounding environment affects one's psychological security level. Through the surrounding environment, one acquires expertise and experiences that make him/her feel secure.

3)- Physical and health-related factors: One's health and physical strength affects the degree to which he/she enjoys psychological security. That is because enjoying good health enables one to serve himself/herself and move freely.

4)- Economic factors: Suffering from poor financial conditions negatively affects one's stability and sense ofpsychological security. It negatively affects one's capability to meet his/her own needs, and desires and family needs. Hence, it leads to experiencinganxiety and distress (Al-Nahi, 2002: 16; Hasan and Salem, 2006: 173).

\subsection{Theories About Psychological Security}

There are various theories about psychological security. The researchers presented below some of those theories: 


\subsubsection{Maslow's Theory}

The psychologist that provided attention the most for psychological security and human needs is Maslow.There are many the studies that shed a light on psychological needs of children, such as: the need for security. Almost all of those studies shed a light on Maslow's ideas. Maslow conducted a study in 1943 which is titled (A Theory of Human Motivation). Through the latter study, Maslow develops a theory named (the hierarchy of needs). Through this theory, Maslow suggests that there are five types of needs. He arranges those needs in the form of a pyramid. The physiological needs are located at the bottom of the pyramid. As for the need for self-actualization, it is located at the top of the pyramid. The latter needaffects one's behavior. One learns the behaviors needed for meeting his/her needs.

Maslow suggests that the needs displayed in the pyramid are basic needs. He suggests that those needs are connected with each other. He adds that the needs are arranged in the pyramid based on their significance. The bottom of the pyramid includes the most significant needs. Once one meets any of the needs in thispyramid, he/she shall seek meeting the need that's placed above it in the pyramid. Meeting all the needs in Maslow's pyramid shall regulate one's behavior and make his/her life stable (Maslow, 1943, Al-Hafni, 1978: 21, Mansour et al., 1978: 117, Sheltz, 1983: 298).

\subsubsection{The Psychoanalytic Theory}

The psychoanalytic theory was developed by Freud. It sheds much light on the biological nature of human. It suggests that humans' sexual desire determines the way they behave. It suggests that the structure of the infants'psycheis very simple and consists from the id only (i.e. the innate instinctual drives). It suggests that the infants' sexual drivesaffects one's behavior currently and in the future. It suggests that thepsyche consists from other elements; ego and super ego. These elements are formed in later stages of life. The ego is represented in one's logic and conscious awareness. Through ego, one can realize the things that are consideredaccepted and the things that are not considered accepted. The ego enables one to meet his/her desires in a logical manner with achieving the maximum benefit. According to Freud, the id and the ego aim at achieving one goal which is meeting the desires. Such desires include the desire to enjoy psychological structure. However, the id and the ego seek meeting one's needs in various methods. Through super ego, onedetermines what's consideredethical for him/her. The super ego is affected by one's interaction with reality and the surrounding environment. The duration that the child spends with his/her parents shall affect his/her super ego. The super-ego is called so because it seeks achieving the things that are opposed by the ego. Through ego, one seeks achieving the goals sought by the id and the super ego.The super-ego is represented in the customs that one learns from his/her parents. These customs are derived from the family, nation and dynasty. The super-ego aims at meeting the demands of the social environment. One is acquainted with such demands through his/her parents (Abu Al-Khair, 2004: 45; Al-Tafeely, 2004: 39).

Karen Horney develops a theory on psychological security. She suggests that there are three (3) attitudes that one may show towards himself/herself and others. Those attitudes include: (moving towards the world, moving against the world, and moving away from the world). Regarding moving towards the world (i.e. compliance), it's represented in showing compliance to others and seeking others' love. It is represented in relying on others to feel safe and secure. The ones who move towards the world have many fears and feel alienated.

Regarding moving against the world (i.e. aggression), it is represented in having a strong need for power. Moving against the world involves being hated and having negative ideas about others' feelings and intentions.It involves rejecting others. Moving away from the world (i.e. withdrawal) involves alienating oneself from others. When one moves away from other world, he/she doesn't seek enjoying a sense of belonging. In fact, he/she creates his/her own world. $\mathrm{He} / \mathrm{she}$ believes thatalienating oneself is the key for avoiding the threats derived from being close to others. $\mathrm{He} /$ she believes that alienating oneself is the key for avoiding any attack launched by others (Kefafi, 2010: 201; Makhdoom, 2014: 89; Ghubari and Sha'eerah, 2015: 175).

Adler conducted an examination for human's personality. He suggests that such examination is called (individual psychology). He suggests that one's behavior is affected by social stimuli. That is because one is a social beingwho has interests in performing social activities. Throughout the developmental stages, one learns the social norms and seeks cooperating and socializing with others. One's desire to receive social attention is an instinctual desire. The nature of one's social relationships with others is determined by the nature of society that one lives in. It is determined by the dominant social norms in the society.

Fromm provides much attention to the social aspect of people's lives. He sheds a light on the things common between people. He sheds a light on the social goals of education. He adds that education plays a significant role in developing one to become capable of doing his/her role in society in the future. Education is a social instrument for 
ensuring that the child's behavior shall be consistent with the needs and demands of society. Fromm describes an ideal society that is dominated by love and brotherhood. In this ideal society, no one shall experience oppression nor has to be submissive. The latter society is based on humanitarian values. It provides people with opportunities to create things instead of destroying things. Fromm adds that one has several basic needs that must be met in order for one to adjust socially. Such needs include: the need for enjoying social belonging, the need for having social discipline, the need for having an identity and the need for enjoying pride (Dawood and Al-Obaidi, 1990; 167, 176).

\subsubsection{The Theory of William Platz}

The theory of William Platz sheds a light on security. It suggests that enjoying a sense of psychological security is something essential for one. It suggests that one may enjoy a sense of psychological security through relying on others. In this case, one enjoysa sense of (reliance-basedsecurity).Enjoying reliance-based security indicates that one isn't mature. It's attributed to the fact that one used to rely much on his/her parents or the caregiver during the childhood stage.However, in order for one to be mature, he/she must seek enjoying autonomy-based security.The latter security is a conscious state of mind that is associated with one's acceptance for his/her acts. Enjoying autonomy -based security requires acquiring new skills that enable one to meet his/her needs and solve his/her problems by himself/herself.Platz suggests that one can't meet the demands of society without receiving support from others and feeling loved by others. He adds that education aims at making children enjoy a high psychological security level. That is because psychological security positively affects children's development. It's because psychological security positively affects the one's self-satisfaction and love relationships in later stages in life (Joward, 1988: 39).

\subsection{Psychological Security From an Islamic Perspective}

Islam aims at raising one's psychological security level. Under the Islamic rules, the constituents of faith include: acknowledging the existence of Allah, judgment day and destiny.Such acknowledgment makes one enjoy a high psychological security level. It makes one feelssafeand emotionally stable. In addition, Islam frees one from the fear of death. That is because Islam suggests that death is a pathway for crossing over to the afterlife where Muslims shall experience safety permanently.

Islam suggests that Allah is the disposer of all affairs. Having this belief makes one feels safe. It makes one enjoys a high psychological security level. It is addressed through the following verses of the Holy Quran: (And whoever fears Allah - He will make for him a way out (2). And will provide for him from where he does not expect. And whoever relies upon Allah - then He is sufficient for him. Indeed, Allah will accomplish His purpose. Allah has already set for everything a [decreed] extent (3) (Sorah At-Talaq (The Divorce).

Islam suggests that the need for security is a basic need. The teachings of Islam emergedhundreds of years before Maslow proposed his ideas. Islam suggests that Allah rewards believers through meeting their physiological needs (i.e. food and water) followed by their needs for safety and security (Al-Tabreezy, 1985: 845). That manifests through the following verse: (Who hath fed them against hunger and hath made them safe from fear) (Quraish: 4)

\subsection{Disability}

Disabled people exist in all societies. Having a disability hinders one from doing his/her daily life tasks efficiently like his/her normal peers. Disabled individuals are in need forreceiving opportunities to learn and grow. They are in need for receiving opportunities to live like other normal individuals in society. However, they have special needs that must be met.

Disabilities differ from one to another. In fact, there are several classifications for disabilities. To illustrate more, some classifications are based on the type of the disability. For instance, the types of disabilities include: autism, mental retardation and learning difficulties. Some classifications are based on the severity of the disability. For instance, a disability may be a mild, severe or moderate disability. Some classifications are based on the extent of prevalence of the disability in the world. For instance, some disabilities are very prevalent and other disabilities are less prevalent (Al-Khateeb and Al-Hadeedi, 2005: 15, Biryan et al., 2012: 98-100).

According to educators and scholars, the children who suffer from a very prevalentdisability include the following ones:

- Children with learning difficulties: They include the children who face learning problems that are attributed to neurological problems. They include the children who show low academic achievement that may be attributed to family problems, lack of motivation or etc. 
- Children with language or speech disorders: They include the children who suffer from a seriousdisorder in the articulation of sounds. They include the children who suffer from a speech sound disorder or a language delay. They include the children who suffer from problems in the development of the expressive or receptive language.

- Children with attention deficit hyperactivity disorder (ADHD): They suffer fromexcessive activity, and difficulties in paying attention. They act without taking into consideration the consequences of their acts. Their acts are repetitive and frequent.

- Children with mental retardation and children with developmental or intellectual disability: Those children suffer from poor cognitive capabilities which are below average. They also suffer from poor adjustment capabilities.

- Children with behavioral or emotional disturbance: They include the children who showbehavioral or emotional responses that differ from the counterpart responses of their normal peers. They include the children who suffer from behavioral or emotional responses that are inconsistent withthe ones who belong to the same race, or culture. Such disturbed responsesnegatively affect the outcomes of the educational process. They negatively affect one's academic, social and professional performance. They negatively affect one's personal skills.

According to educators and scholars, the children who suffer from a less prevalent disability include the following children:

- Children with health impairments(i.e. the children in need for special healthcare): They include the children who suffer from a medical condition that negatively affects their development and academic achievement. Such a medical condition may be congenital or start in later stages in life.

- Autistic children: They include the children who suffer from a disorder that affects their social development and capability to communicate with others. Autism manifests through abnormal behaviors, such as: repetitive movements.

- Children with multiple disabilities: They include the children who suffer from several disabilities, such as:the ones who suffer from mental retardation and visual impairment jointly. Having multiple disabilities shall hinder one from doing daily life activities. The children with multiple disabilities must be provided with intensive care and special educational services.

- Children with developmental disorder: They include the children who suffer from a delay in the physical, cognitive, emotional, or social development or problems in adjustment. Children with developmental disorder must be provided with support services and special education.

- Children with physical disability: They include the children who suffer from a bone-related disability which may be attributed to a congenital deformityor a disease (e.g.poliomyelitis and bone tuberculosis).

- Deaf children and children with hearing impairment: They include the children who can't process the auditory information through hearing. The hearing impairment negatively affects the academic achievement of children. It may be a temporary or permanent impairment. The children with hearing impairment may use assistive technology to improve their hearing capability.

- Children with visual impairment: They include the children who are blind. They include the children who suffer from a visual impairment that negatively affects their academic achievement. The visual acuity of the children with visual impairment is within the range of (20/70 -20/400). The state of blindness may be congenital or start in later stages in life

- Children with acquired brain injury: The acquired brain injury is attributed to an external force that leads to full or partial functional disability. Such a disability negatively affects children academic achievement. For instance, the children with acquired brain injury usually show problems in remembering things, and concentrating. They also suffer from language disability. Some acquired brain injuries are severe. In such cases, the teacher may think that the child suffers fromepilepsy

- The children who are suffer from blindness and deafness jointly: They are represented in the children who suffer from visual and auditory impairments jointly. Thus, those children suffer from major problems in communication. The visual acuity of those children is $20 / 70$ or less and theirhearing capacity is 30 decibels or less (Biryan et al., 2012: 118-537, Al-Khateeb and Al-Hadeedi, 2007: 59-288) 
Regardless of the type and severity of the disability that the child suffers from, he/she shall be in need for receiving special education. He/she shall be in need for receiving rehabilitation and support services. Providing those children with such education and services shall enable them to unleash their potentials. Those children must receive such education and services because they differ from their normal peers in one of the following areas or several ones: the cognitive, physical, sensory, behavioral, language, and educational areas. Hence, the Qatari government identifies the types of disabilities that must be associated with special education and support services. These types are identified through table (7).

\section{Methodology and Procedures}

\subsection{Population}

The tem (population) refers to all the elements that are targeted by a researcher for exploring a specific phenomenon (Melhem, 2010: 269). In the present study, it involves all the disabled children in Qatar who are enrolled in schools

\subsection{Sample}

Sample refers to the elements selected from the study's population based on specific scientific rules. It represents the population (Al-Safawi, 2008: 27). In the present study, the sample consists from 2735 female and male disabled children. The researchers obtained the consent of the parents on engaging their children in the study.

\subsection{Characteristics of the Sample}

The researchers calculated the frequencies and percentages to identify the characteristics of the sample. Such characteristics include: (academic achievement, and the students' status). It was found that most of the respondents are males (i.e. $69.76 \%$ ). It was found that $30.2 \%$ of the respondents are females. It was found that $89.80 \%$ of the respondents live in stable family. It was found that $6.25 \%$ of the respondents live in families in which the parents are divorced. It was found that $3.95 \%$ of the respondents lives in families in which one of the parents passed away

Regarding the type of disability, $31.85 \%$ of the respondents suffer from multiple disabilities. $17.33 \%$ of the respondents suffer from learning difficulties. $15.36 \%$ of the respondents are slow learners. $14.41 \%$ of the respondents have an intellectual disability. $7.53 \%$ of the respondents suffer from autism. $4.61 \%$ of the respondents suffer from hearing impairment. 3.99\% of the respondents suffer fromattention deficit hyperactivity disorder (ADHD). $2.34 \%$ of the respondents suffer from a healthimpairment that negatively affects their learning outcomes. $1.46 \%$ of the respondents suffer from a visual impairment. $0.91 \%$ of the respondents suffer from a language or speech disorder. $0.22 \%$ of the respondents suffer frompsycho-behavioral disturbance that negatively affects their learning outcomes.

Most of the respondents (i.e. 90.93\%) are enrolled in public schools. 9.07\% of the respondents are enrolled in private schools. Most of the respondents (i.e. 66.40\%) hold the Qatari nationality. 33.60\% of the respondents don't hold the Qatari nationality

\subsection{Instrument}

The researchers used a psychological security scale for disabled children. The latter scale was developed by Hazem (2017).

Description for the scale and the criteria used for classifying means:

The scale consists from 20 items. It sheds a light on four areas; (personal security, social acceptance, emotional security, and self-esteem). The options in the scale are: (often, sometimes and rarely). These options represent the following scores respectively: 3,2 and 1. The teacher should fill in the forms of the scale on behalf of the student. $\mathrm{He} /$ she should do that after getting the consent of the concerned parents.

\subsection{Validity of the Scale}

Measuring validityplays a significant role in developing psychometric tests. The construct validity and internal consistency of the study's scale were measured

\subsubsection{Internal Consistency}

Pearson correlation coefficient values were calculated to identify the relevancy between each item and the area it belongs to. That was done to measure the internal consistency. The table below presents the Pearson correlation coefficient value of each item. 
Table 1. Pearson correlation coefficient values for identifying the relevancy between each item and the area it belongs to

\begin{tabular}{rrrrrrrr}
\hline \multicolumn{2}{l}{ Personal security } & \multicolumn{2}{c}{ Social acceptance, } & \multicolumn{2}{c}{ Emotional security } & \multicolumn{2}{c}{ Self-esteem } \\
\hline Item No. & P value & Item No. & P value & Item No. & P value & Item No. & P value \\
\hline 1 & $* * 0.459$ & 7 & $* * 0.690$ & 12 & $* * 0.614$ & 17 & $* * 0.308$ \\
\hline 2 & $* * 0.499$ & 8 & $* * 0.671$ & 13 & $* * 0.458$ & 18 & $* * 0.455$ \\
\hline 3 & $* * 0.362$ & 9 & $* * 0.712$ & 14 & $* * 0.447$ & 19 & $* * 0.411$ \\
\hline 4 & $* * 0.456$ & 10 & $* * 0.507$ & 15 & $* * 0.504$ & 20 & $* * 0.489$ \\
\hline 5 & $* * 0.455$ & 11 & $* * 0.705$ & 16 & $* * 0.570$ & - \\
\hline 6 & $* * 0.523$ & - & - & - & - & -
\end{tabular}

$(* *)$ : This sign means that the value is statistically significant at the statistical significance level of $(a=0.01)$

Based on Table 1, all the Pearson correlation coefficient values are statistically significant at the statistical significance level of $(a=0.01)$. They are within the range of $(0.308-0.712)$. They indicate that the internal consistency of the scale is high

\subsubsection{Construct Validity}

The construct validity of the scale was measured. That was done through calculating the correlation coefficient value of each area. Table 2 presents those values.

Table 2. The correlation coefficient value of each area

\begin{tabular}{rrrr}
\hline Area No. & Area & The correlation coefficient value \\
\hline 1 & Personal security & $* * 0.632$ \\
\hline 2 & Social acceptance, & $* * 0.785$ \\
\hline 3 & Emotional security & $* * 0.730$ \\
\hline 4 & Self-esteem & $* * 0.614$
\end{tabular}

$(* *)$ : This sign means that the value is statistically significant at the statistical significance level of $(a=0.01)$

Based on Table 2, all the correlation coefficient values are statistically significant at the statistical significance level of $(\mathrm{a}=0.01)$. They are within the range of $(0.614-0.785)$. They indicate that the construct validity of the scale is high.

\subsection{Reliability of the Scale}

The researchers measured the reliability of the scale through calculating the Cronbach alpha coefficient value. The latter value is 0.899 . It indicates that the reliability of the scale is high.

\subsection{The Distribution of the Forms of the Scale}

The forms of the scale were distributed during the first semester of the academic year (2019/2020). They were distributed at public schools and private schoolsin Qatar. The researchers held meetings with teachers in order to illustrate the way of filling the forms on behalf of the student. They informed the teachers about the guidelines. The researchers held meetings with teachers in order to illustrate the ethics to comply with while filling the forms. Such ethics include: obtaining a written consent from the parents/ caregivers.

\subsection{Statistical Analysis}

The SPSS program was used. Cronbach alpha coefficient value was calculated and the t-test was conducted. The analysis of variance was conducted. The least significant difference (LSD) test was conducted.

\section{Results and Discussion}

\subsection{Results and Discussion Related to the First Question}

Q.1. What is the psychological security level of the disabled children in Qatar? 
To identify the psychological security level of the disabled children in Qatar, means and standard deviations were calculated. Those means are arranged based on the descending order. They are presented in Table 3 below:

Table 3. The means and standard deviations of the psychological security level of the disabled children in Qatar

\begin{tabular}{llllll}
\hline No. & Area & Mean & Std. & Rank & Level \\
\hline 3 & Emotional security & 2.31 & 0.318 & 1 & Moderate \\
\hline 2 & Social acceptance & 2.21 & 0.387 & 2 & Moderate \\
\hline 1 & Personal security & 2.12 & 0.265 & 3 & Moderate \\
\hline 4 & Self-esteem & 2.03 & 0.272 & 4 & Moderate \\
\hline \multicolumn{2}{r}{ Total } & 2.17 & 0.218 & Moderate \\
\hline
\end{tabular}

Based on Table 3, the psychological security level of the disabled children in Qataris moderate. That is because the overall mean is 0.218 . The overall standard deviation is 0.218 . The mean of the (emotional security) area is 2.31. It is ranked first. The standard deviation of the latter area is 0.318 . The mean of the (social acceptance) area is 2.21 which is ranked second. The standard deviation of the latter area is 0.387 . The mean of the (personal security) area is 2.12 which is ranked third. The standard deviation of the latter area is 0.265 . The mean of the (self-esteem) area is 2.03 which is ranked fourth. The standard deviation of the latter area is 0.272 . The means in Table 3 are within the range of (0.265- 0.387). They are moderate.

The mean of the (emotional security) area is ranked first. That indicates that promoting emotional security among disabled children plays a significant role in promoting psychological security among them. It indicates that meeting the basic needs of disabled children shall make them love their school and enjoy a high psychological security level.

The mean of the (social acceptance) area is ranked second. That is attributed to the fact that people's social perceptions for disabled children have changed. It is attributed to the fact that positive changes have occurred to the way people interact with disabled children.Such changes increased the extent of accepting disabled children in society. They increased the degree to which disabled children accept others. They increased the amount of love shown to disabled people. They shall make disabled children feel safe and enjoy a high psychological security level.

The psychological security level of the disabled children in Qatar is moderate. However, the mean of the (personal security) area is ranked third. That indicates that disabled children feel appreciated, respected and loved by others. According to Maslow, such feelings shall make disabled children enjoy a high psychological security level. It shall make the child free from any fear and motivated to meet other needs, like the need for feel happy.

The mean of the (self-esteem) area is ranked fourth. That indicates thatthe security is derived from one's capability to establish satisfactory and healthy relationships with friends.

\subsection{Results and Discussion Related to the Second Question}

Q.2. Is there any statistically significant difference between the respondents' psychological security levels which can be attributed to their (gender, family type, disability type, and the type of institution)?

The independent sample t-test was conducted to identify whether there is any statistically significant difference between the respondents' psychological security levels which can be attributed to (gender or type of institution). The one way analysis of variance (ANOVA) was conducted to identify whether there is any statistically significant difference between the respondents' psychological security levels which can be attributed to (family type, or disability type). The detailed results related to the second question are presented below:

First: Results related to gender:

The independent sample t-test was conducted to identify whether there is any statistically significant difference between the respondents'psychological security levels which can be attributed to (gender). The results of the latter test are presented in Table 4. 
Table 4. The results of the independent sample t-test was conducted to identify whether there is any statistically significant difference between the respondents' psychological security levels which can be attributed to (gender)

\begin{tabular}{|c|c|c|c|c|c|c|}
\hline Gender & Frequency & Mean & Std. & df. & $\mathrm{T}$ value & Sig. \\
\hline Male & 1908 & 2.17 & 0.216 & \multirow{2}{*}{2733} & \multirow{2}{*}{$0.164-$} & \multirow{2}{*}{0.870} \\
\hline Female & 827 & 2.17 & 0.222 & & & \\
\hline
\end{tabular}

Based on Table 4, there isn't any statistically significant difference - at the statistical significance level of a $=0.05$ between the respondents' psychological security levels which can be attributed to (gender). That is because the $t$-value is -0.164 which isn't statistically significant at the statistical significance level of $a=0.05$. The later result may be attributed to the fact that male and female disabled children share similar conditions at school. It may be attributed to the fact that male and female disabled children are provided with similar services. The Qatar society is an eastern society that gives priority to males. However, male and female disabled children are treated equally in the Qatar society. That is because those children are in need for special care.

Second: Results related to family type:

The one way analysis of variance (ANOVA) was conducted to identify whether there is any statistically significant difference between the respondents' psychological security levels which can be attributed to (family type). The results of the latter analysis are presented in Table 5:

Table 5. The results of the one way analysis of variance (ANOVA) to identify whether there is any statistically significant difference between the respondents' psychological security levels which can be attributed to family type

\begin{tabular}{|c|c|c|c|c|c|}
\hline $\begin{array}{l}\text { Source } \\
\text { variance }\end{array}$ & Sum of squares & & Mean square & f-value & Sig. \\
\hline Between groups & 0.102 & 2 & 0.051 & & \multirow{3}{*}{0.341} \\
\hline Within groups & 129.433 & 2732 & 0.047 & 1.076 & \\
\hline Total & 129.535 & 2734 & & & \\
\hline
\end{tabular}

Based on Table 5, there isn't any statistically significant difference - at the statistical significance level of a $=0.05$ between the respondents' psychological security levels which can be attributed to (family type). That is because the $\mathrm{f}$-value is 1.076 which isn't statistically significant at the statistical significance level of $a=0.05$. The later result may be attributed to the fact that the families in Qatar are provided with the required expertise for dealing with their disabled children.

Third: Results related to disability type

The one way analysis of variance (ANOVA) was conducted to identify whether there is any statistically significant difference between the respondents' psychological security levels which can be attributed to (disability type). The results of the latter analysis are presented in Table 6:

Table 6. The results of the one way analysis of variance (ANOVA) to identify whether there is any statistically significant difference between the respondents' psychological security levels which can be attributed to (disability type)

\begin{tabular}{|c|c|c|c|c|c|c|}
\hline $\begin{array}{l}\text { Source } \\
\text { variance }\end{array}$ & Sum of squares & df. & Mean square & f-value & & \\
\hline Between groups & 2.589 & 10 & 0.259 & & \multirow{3}{*}{5.554} & \multirow{3}{*}{$* 0.00$} \\
\hline Within groups & 126.946 & 2724 & 0.047 & & & \\
\hline Total & 129.535 & 2734 & & & & \\
\hline
\end{tabular}

*: This sign means that the value is statistically significant at the statistical significance level of $(a=0.05)$ 
Based on Table 6, there are statistically significant differences-at the statistical significance level of $a=0.05$ - between the respondents' psychological security levels which can be attributed to the (disability type). That is because the $\mathrm{f}$-value is 5.554 which is statistically significant at the statistical significance level of $a=0.05$. In order to identify the ones whose the differences are for their favor, the least significant difference (LSD) test was conducted. The results of the latter test are presented in Table 7 below.

Table 7. The results of the least significant difference (LSD) test to identify the ones whose the differences are for their favor

\begin{tabular}{|c|c|c|c|c|c|c|c|c|c|c|c|c|}
\hline No. & Disability type & 1 & 2 & 3 & 4 & 5 & 6 & 7 & 8 & 9 & 10 & 11 \\
\hline 1 & $\begin{array}{l}\text { Children with an } \\
\text { intellectual disability }\end{array}$ & - & $\checkmark$ & - & - & - & - & - & - & - & - & - \\
\hline 2 & Autistic children & - & - & - & - & - & - & - & - & - & - & - \\
\hline 3 & $\begin{array}{l}\text { Children with } \\
\text { hearing impairment }\end{array}$ & - & $\checkmark$ & - & - & - & - & - & - & - & - & - \\
\hline 4 & $\begin{array}{r}\text { Children with visual } \\
\text { impairment }\end{array}$ & - & & - & - & - & - & - & - & - & - & - \\
\hline 5 & $\begin{array}{l}\text { Children with } \\
\text { learning difficulties }\end{array}$ & - & $\checkmark$ & - & - & - & $\checkmark$ & - & - & $\checkmark$ & - & - \\
\hline 6 & $\begin{array}{l}\text { Children with } \\
\text { multiple disabilities }\end{array}$ & - & $\checkmark$ & - & - & - & - & - & - & - & - & - \\
\hline 7 & $\begin{array}{rr}\begin{array}{l}\text { Children } \\
\text { attention }\end{array} & \begin{array}{r}\text { with } \\
\text { deficit }\end{array} \\
\text { hyperactivity } \\
\text { disorder (ADHD) }\end{array}$ & - & $\checkmark$ & - & - & - & - & - & - & - & - & - \\
\hline 8 & $\begin{array}{c}\text { Children who are } \\
\text { slow learners }\end{array}$ & - & $\checkmark$ & - & - & - & - & - & - & - & - & - \\
\hline 9 & $\begin{array}{lr}\text { Children } & \text { with } \\
\text { language or speech } \\
\text { disorder }\end{array}$ & - & & - & - & - & - & - & - & - & - & - \\
\hline 10 & $\begin{array}{lr}\text { Children with from } \\
\text { psycho-behavioral } \\
\text { disturbance that } \\
\text { negatively affects } \\
\text { their learning } \\
\text { outcomes. }\end{array}$ & - & $\checkmark$ & - & - & - & - & - & - & $\checkmark$ & - & - \\
\hline 11 & $\begin{array}{l}\text { Children with health } \\
\text { impairment that } \\
\text { negatively affects } \\
\text { their learning } \\
\end{array}$ & $\checkmark$ & $\checkmark$ & - & $\checkmark$ & $\checkmark$ & - & $\checkmark$ & $\checkmark$ & $\checkmark$ & - & - \\
\hline
\end{tabular}

Based on Table 7, the following results are concluded:

- A comparison was conducted between the autistic children and the children with an intellectual disability. It was found that the differences are for the favor of the children with an intellectual disability.

- A comparison was conducted between the autistic children and the children with a hearing impairment. It was found that the differences are for the favor of the children with a hearing impairment 
- A comparison was conducted between the children with learning difficulties, the autistic children, the children with multiple disabilities and the children with language or speech disorder. It was found that the differences are for the favor of the children with learning difficulties

- A comparison was conducted between the children with multiple disabilities and the autistic children. . It was found that the differences are for the favor of the children with multiple disabilities

- A comparison was conducted between the children with attention deficit hyperactivity disorder (ADHD) and the autistic children. It was found that the differences are for the favor of the childrenwith attention deficit hyperactivity disorder (ADHD)

- A comparison was conducted between the children who are slow learners and the autistic children. It was found that the differences are for the favor of the children who are slow learners

- A comparison was conducted between the children withpsycho-behavioral disturbance that negatively affects their learning outcomes, autistic children and children with language or speech disorder. It was found that the differences are for the favor of the children withpsycho-behavioral disturbance that negatively affects their learning outcomes

- A comparison was conducted between the children with health impairment that negatively affects their learning outcomes, children with an intellectual disability, autistic children, children with visual impairment, children with learning difficulties, children with attention deficit hyperactivity disorder (ADHD), children who are slow learners, and children with language or speech disorder. It was found that the differences are for the favor of the children with health impairment that negatively affects their learningoutcomes.

The latter results may be attributed to the differences between the programs that the children are enrolled at. To be specific, specialists develop customized plans for teaching disabled children and developing them in all areas

Fourth: Results related to the institution type:

The independent sample t-test was conducted to identify whether there is any statistically significant difference between the respondents' psychological security levels which can be attributed to the (institution type). The results of the latter test are presented in Table 8.

Table 8 . The results of the independent sample t-test was conducted to identify whether there is any statistically significant difference between the respondents' psychological security levels which can be attributed to the (institution type)

\begin{tabular}{ccccccc}
\hline Gender & Frequency & Mean & Std. & df. & T value & Sig. \\
\hline Public institution & 2487 & 2.17 & 0.219 & 2733 & 2.108 & $* \mathbf{0 . 0 4}$ \\
\hline Private institution & 248 & 2.14 & 0.197 & & & \\
\hline
\end{tabular}

*: This sign means that the value is statistically significant at the statistical significance level of $(\mathrm{a}=0.05)$

Based on Table 8, there arestatistically significant differences -at the statistical significance level of $a=0.05$ - between the respondents' psychological security levels which can be attributed to the (institution type). That is because the $\mathrm{t}$-value is 2.108 which is statistically significant at the statistical significance level of $\mathrm{a}=0.05$. The later differences are for the favor of the students enrolled in public institutions. The latter result indicates that the quality of the public services provided for disabled children is high

\section{Conclusion}

The researchers concluded the following results:

1- The psychological security level of the disabled children in Qatar is moderate

2- The mean of the (emotional security) area is ranked first and the mean of the (self-esteem) area is ranked last.

3- There isn't any statistically significant difference between the psychological security levels of disabled children which can be attributed to gender. 
4- There isn't any statistically significant difference between the psychological security levels of disabled children which can be attributed to family type. The family types include: the stable families, divorced families, and families in which a parent passed away.

5- There is a statistically significant difference between the psychological security levels of disabled children which can be attributed to the (disability type).

6- There is a statistically significant difference between the psychological security levels of disabled children which can be attributed to the (institution type). To illustrate more, the psychological security level of the disabled children enrolled in public schools is higher than the counterpart level of the disabled children enrolled in private schools.

\section{Recommendations}

In the light of the study's results, the researchers recommend the following:

- Developing programs for developing teachers at private and inclusive schools. Such programs should promote awareness among teachers about the way of dealing with disabled children. Developing such programs shall raise the psychological security levels of disabled children

- Enacting a law that obliges the parents of disabled children to enroll in training programs that enable them to raise the psychological security levels of their disabled children. The researchers believe that those parents must finish such programs in order to get the financial support that is given by the government.

- Enrolling disabled children in programs that aim at raising their psychological security levels.

- Establishing a phone consultation department in order to address the psychological problems that disabled children and parents suffer from fast.

\section{Suggestions for Researchers}

The researchers recommend the following:

- Conducting a study that aims at exploring the psychological security level of the disabled children in Arab countries

- Conducting a study that aims at conducting a comparison between the psychological security level of disabled children in USA and the counterpart level of disabled children in Finland

- Conducting a study that aims at exploring the effectiveness of a proposed training program in enabling parents and teachers to raise the psychological security level of disabled children.

\section{Acknowledgment}

This research approved from Qatar University Institutional Review Board (QU-IRB 1154EA/19)

\section{Contribution}

Dr. Abdulnaser led this research, focused on literature and conclusion, and supervised the application of the questionnaire Dr. Zahra focused on the conclusion and made some translation. Dr. Sara took the statistic side and made the final editing

\section{References}

Abu Al-Khair, \& Abed Al-Kareem Qasem. (2004). Growth: from the pregnancy stage till the adolescence stage. Amman. Dar Wa'el.

Al- Hafni, \& Abed Al-Menem. (1978). The psychology and psychoanalysis encyclopedia, Part 1. Beirut. Madbouli. Dar Al-Odeh.

Al-Esawi, Abed Al-Rahman Mohammed. (2003). Psychometric measures and tests. Alexandria. Dar Al-Munsha'ah.

Al-Kenani, Salah. (1988). The extent of meeting the needs in Maslow's need pyramid in the Egyptian environment. The Faculty of Education Journal- Masnsoura University, (9), 81-126.

Al-Khateeb, Jamal, \& Al-Hadeedi, Mona. (2007). Introduction to special education. Kuwait. Al-Falah Bookshop.

Al-Nahi, Isam Mohammad Abed Al-Rida. (2002). Psychological security and its relationship with Emotional over-excitability among basketball players. MA thesis. Mousel University. Faculty of physical education.

Al-Otoom, Adnan. (1997). The impact of listening to the Holy Quran on psychological security. The Journal of Um Al-Qura University, Educational, Psychological and Social Studies, (16), 31-50. 
Al-Qaryooti, Yousif, Al-Sartawi, Abed Al-Aziz, \& Al-Smadi, Jameel. (1995). Introduction to special education. Dubai, Dar Al-Qalam.

Al-Sayed, Abed Al-Haleem, Khalifah, Abed Al-Lateef, Abdullah, Mu’taz, Faraj, Tareef, \& Abu Sree', Osama. (1989). Social psychology (2nd ed.). Dar Aton. Cairo.

Al-Shareef, Mohammad Mousa. (2003). Psychological security. KSA. Dar Al-Andalus Al-Khadra'.

Al-Tabreezy, Mohammad bin Abdullah. (1985). Meshkat Al-Masabeeh (3rd ed.). Al-Maktab Al-Islami, Beirut.

Al-Tafeely, Imtithal Zain Al-Deen. (2004). Developmental psychology from childhood stage till elderly stage. Beirut. Dar Al-Manhal Al-Lebnani.

Aqra', Aya Mohammad. (2005). Enjoying psychological security and its impacts on some variables among the students enrolled in Al-Najah National University. MA thesis, Gaza. Al-Najah National University

Ateye, Ahmad. (1994). Psychological needs and the methods of meeting them among secondary school students. The Journal of the Faculty of Education, Ain Shams University, (20).

Biryan, B., Smith, D., \& Biryan, B. (2012). Teaching students with special needs in inclusive classrooms. Translated by Mohammad Hasan Ismail. Jordan. Dar Al-Feker.

Dawood, Aziz Hana, \& Al-Obaidi, NathemHashem. (1990). Positive psychology. The Ministry of Higher Education and Scientific Research. Baghdad University.

Eid, Mohammad Ibrahim. (1990). Introduction to social psychology-Lectures in social psychology. Cairo. Ain Shams University. The Anglo Egyptian Bookshop.

Ghubari, Tha'er Ahmad, \& Sha'eerah, KhaildSameerah. (2015). Personality-related psychology (1st ed.). Amman. Al-Mujrama' Al-Arabi Bookshop.

Habeeb, LaithHazim. (2013). Developing a psychological security scale for students with special needs in Nineveh. The Journal of Tikreet University for Sciences, 20(12). 450-493.

Hasan, Al-Hareth Abed Al-Hameed, \& Salem, GasanHussain. (2006). Security-related psychology (1st ed.). Beirut: Al-Dar Al-ArabeyeLelulum.

Jaber, Mohammad. (1996). Some demographic variables related to psychological security. The Journal of Psychology, 10(39), The General Egyptian Book Organization, 80-93.

Joward, Sydney. (1988). Healthy personality: A study for personality through psychology. Translated by HamadWali Al-Karbooli and Muwafaq Al-Hamadani. Baghdad: The Printing House of the Ministry of Higher Education and Scientific Research.

Kefafi, Ala' Al-Deen. (2010). Theories on personality: Development, growth and diversity (1st ed.). Amman. Dar Al-Feker.

Makhdoom, Ayoob Al-Tafi. (2014). Theories on personality. Amman. Dar Maktabet Hamid.

Mansour, Talat, Al-Sharqawi, Anwar, Izz Al-Deen, Adel, \& Abu Ouf, Farooq. (1978). Foundations of general psychology. Cairo. Ain Shmas University.

Odeh, Fatmah. (2020). The psychological-social climate and its relationship with emotional security and the strength of the ego among the female students enrolled in the Islamic University in Gaza. Unpublished MA thesis. Gaza. The Islamic University in Gaza.

Rajeh, Ahmad Izzat. (2011). Foundations of psychology. Cairo. Dar Al-Manaber.

Rezeq, Sa’d. (1979). Psychology encyclopedia (2nd ed.). Beirut. Al-Mawsooa Al-Arabeye.

Sheltz, Daroon. (1983). Theories on personality. Translated by Wali Al-Karbooli and Abed Al-Rahman Al-Qaisi. Baghdad. The Printing House of Baghdad University.

Zahran, Hamid Abed Al-Salam. (1989). Psychological security: A fundamental pillar for the Arab national security. Educational Studies, 4. Part 19.

Zahran, Hamid. (2003). Psychological security: A fundamental pillar for the Arab national and global security. Studies in psychological wellbeing and counseling. Cairo. Alam Al-Kutub, pp. 83-105. 


\section{Appendix}

Dear Teacher,

The researchers presented below the scale. This scale aims at identifying the psychological security level of respondents. You should answer on behalf of the respondent. You should choose one of the following answers (sometimes, often and rarely). You should answer based on your observation for the student and interaction with him/her.

Please, fill in the form of the scale with accuracy and integrity. You can refrain from engaging in the study at any time you want. You may refrain from answering any question in the scale.

The data collected through the scale shall remain confidential. It shall be used for meeting scientific goals only. It shall not be published nor exchanging with any on. Please, obtain a written consent from the parent/ or caregiver before you start filling in the scale form. The consent form is attached with the scale.

\section{Consent:}

I am ------------. I am the parent/caregiver of I approve taking notes on my daughter/ son by the teacher in order to fill in the form of the psychological security scale for disabled school students. I approve using the collected data for meeting scientific research-related goals.

Signature:

Date:

Please, circle the option you want:

$\square$ I would like to be provided with the results reached through using the scale

$\square$ I don't want to be provided with the results reached through using the scale 


\section{The Psychological Security Scale for Disabled School Students}

\begin{tabular}{|c|c|c|}
\hline No. & Often & Sometimes \\
\hline 1 & $\begin{array}{l}\text { The student's interaction with } \\
\text { his/her colleagues makes } \\
\text { him/her feel safe }\end{array}$ & \\
\hline 2 & The student has a high morale & \\
\hline 3 & $\begin{array}{l}\text { The student prefers to be absent } \\
\text { whenever it's possible }\end{array}$ & \\
\hline 4 & $\begin{array}{l}\text { The student loves his/her school } \\
\text { and like going to it }\end{array}$ & \\
\hline 5 & $\begin{array}{l}\text { The interference of the teachers } \\
\text { in the student's personal } \\
\text { decision annoys the student }\end{array}$ & \\
\hline 6 & $\begin{array}{l}\text { The students appears to be } \\
\text { jealous from his/her colleagues }\end{array}$ & \\
\hline 7 & $\begin{array}{l}\text { The student likes to interact } \\
\text { with his/her colleagues }\end{array}$ & \\
\hline 8 & $\begin{array}{l}\text { The student is treated in a } \\
\text { lovely manner by his/her } \\
\text { colleagues }\end{array}$ & \\
\hline 9 & $\begin{array}{l}\text { The student is provided with } \\
\text { support by his/her colleagues } \\
\text { when needed }\end{array}$ & \\
\hline 10 & $\begin{array}{l}\text { The student desires to run from } \\
\text { schoolfor any reason }\end{array}$ & \\
\hline 11 & $\begin{array}{l}\text { The student's colleagues engage } \\
\text { in the social events of the } \\
\text { student }\end{array}$ & \\
\hline 12 & $\begin{array}{l}\text { The student expresses his/her } \\
\text { feelings of joy and happiness }\end{array}$ & \\
\hline 13 & $\begin{array}{l}\text { The student experiences } \\
\text { difficulty in expressing his/her } \\
\text { feelings }\end{array}$ & \\
\hline 14 & $\begin{array}{l}\text { The student is in need for } \\
\text { showing love to him/her }\end{array}$ & \\
\hline 15 & $\begin{array}{l}\text { The student enjoys a high } \\
\text { self-confidence level }\end{array}$ & \\
\hline 16 & $\begin{array}{l}\text { The student is loved by his/her } \\
\text { friends }\end{array}$ & \\
\hline 17 & $\begin{array}{l}\text { The student is treated kindly by } \\
\text { his/her colleagues }\end{array}$ & \\
\hline 18 & $\begin{array}{l}\text { The student is criticized much at } \\
\text { school }\end{array}$ & \\
\hline 19 & The student is often optimistic & \\
\hline 20 & $\begin{array}{l}\text { The student feels annoyed at the } \\
\text { beginning of the school day }\end{array}$ & \\
\hline
\end{tabular}


The student's code:

The student's age/ school stage: ------

\section{Family type:}

$\square$ Stable family

$\square$ A family in which the parents are divorced

$\square$ A family in which one of the parents passed away

Type of disability:

Type of school:

$\square$ Public school

$\square$ Private school

Nationality

$\square$ Qatari nationality

$\square$ Another nationality

The teacher's name:

The date on which the scale form was filled in: 